\title{
Russia’s Foreign Trade under the Anti-Russian Sanctions
}

\author{
Sergey Kazantsev
}

Institute of Economics and Industrial Engineering of Siberian Branch of the Russian Academy of Sciences, Novosibirsk, Russia

kzn-sv@yandex.ru

\begin{abstract}
Development model based on the export of raw materials and high dependence on external economic conditions are among the main strategic threats to the national security of the Russian Federation in the field of economy. So, a number of states, not without reason, are trying to realize these threats in order to achieve their geopolitical goals by imposing different restrictions, various prohibitions and multiple sanctions. Some results of the analysis of the impact of the anti-Russian sanctions on the Russian foreign trade in 2014-2016 I present in this article. For the sphere of foreign trade, it is shown that the negative impact of prohibitions and sanctions, as well as adverse external and unfavourable internal processes and factors, had a greater impact, first of all, on the fuel and energy, petrochemical and machine-building complexes. The subjects of the Russian Federation with a high concentration of export and import, oil and gas extraction and metal-production were affected stronger than other regions. Along with this, the impact of sanctions and the response of the Russian government are stronger on the export of Russian products than on imports.
\end{abstract}

Keywords: Anti-Russian sanctions, the Russian Federation, import, export, geographical structure of foreign trade JEL classification: F40, F49, H56

\section{Acknowledgements}

The article was prepared within the framework of the Complex program of fundamental research of Siberian Branch of the Russian Academy of Sciences “Interdisciplinary integration studies for 2018-2020", Project No. 22.

\section{Reduction of the Russian Federation Imports}

The state and dynamics of foreign trade of any country, generally, depends on the three groups of factors: the situation in its economy and the credit and financial system; the conjuncture on the world markets; the geopolitical situation in the world. These factors largely determine the volume, dynamics and structure of foreign trade. In 2014-2016, all three groups of factors were unfavourable for the Russian Federation. The decline in investment activity was followed by an economic downturn (Figure 1), which led to a decline in demand for investment and consumer goods, including imported ones.

At the same time, the world prices for the main Russian exports have fallen, which had the effect of the reduction in the positive balance of exports

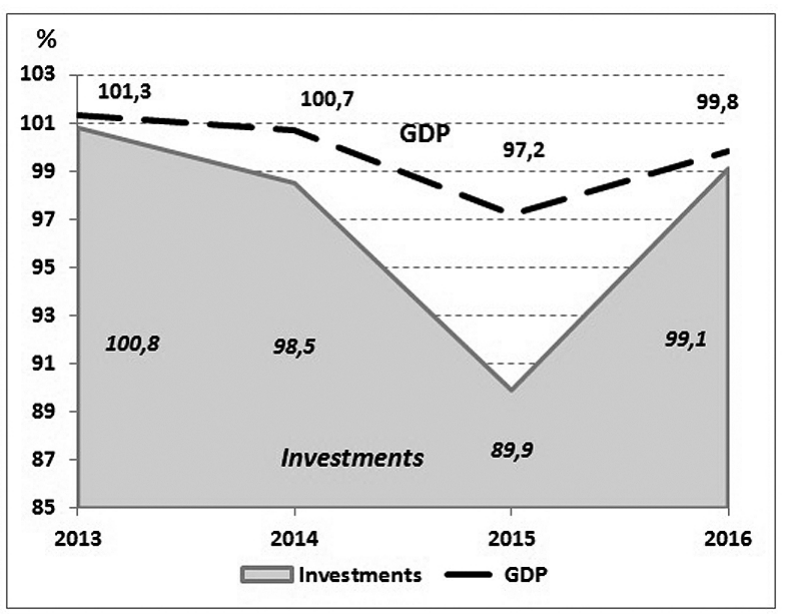

Figure 1. The rate of change of GDP and the investment in fixed assets in 2013-2016 (at comparable prices), \%.

Source: the author on the basis of Rosstat's data (Rosstat, 2017). 
Table 1

Volumes of the Russian imports of certain commodity groups in 2001-2016, millions US dollars

\begin{tabular}{lccc}
\hline \multicolumn{1}{c}{ Commodity group } & $\mathbf{2 0 0 1}$ & $\mathbf{2 0 1 3}$ & $\mathbf{2 0 1 6}$ \\
\hline Food and raw materials & $9,136.7$ & $43,076.1$ & $24,986.4$ \\
Production of fuel and energy complex & $1,023.5$ & $3,613.6$ & $1,530.0$ \\
Petrochemical complex products & $7,523.1$ & $50,129.5$ & $33,815.9$ \\
Wood and its products & $1,307.8$ & $6,641.9$ & $3,379.1$ \\
Ferrous and non-ferrous metals & $2,677.6$ & $22,017.3$ & $11,410.8$ \\
Engineering products & $14,144.8$ & $154,370.4$ & $86,033.2$ \\
Other product groups & $1,464.3$ & $35,436.3$ & $21,011.3$ \\
Imports - total & 37277.8 & 315285.1 & 182166.7 \\
\hline
\end{tabular}

Source: author's calculations on the basis of Rosstat's data (Rosstat, 2017).

Table 2

Average annual change in volumes of the Russian imports in 2002-2013 and in 2014-2016

\begin{tabular}{lcccc}
\hline \multicolumn{1}{c}{ Commodity group } & $\begin{array}{c}\text { Annual average absolute change } \\
\text { in volume, } \mathbf{m l n} \text { US dollars }\end{array}$ & \multicolumn{2}{c}{ Average annual rate of change, \% } \\
\cline { 2 - 4 } & $2002-2013$ & $\mathbf{2 0 1 4 - 2 0 1 6}$ & $\mathbf{2 0 0 2 - 2 0 1 3}$ & $\mathbf{2 0 1 4 - 2 0 1 6}$ \\
\hline Food and raw materials & $2,828.3$ & $-6,029.9$ & 113.8 & 83.4 \\
Production of fuel and energy & 215.8 & -694.5 & 111.1 & 75.1 \\
complex & & & 87.7 \\
Petrochemical complex products & $3,550.5$ & $-5,437.9$ & 117.1 & 79.8 \\
Wood and its products & 444.5 & $-1,087.6$ & 114.5 & 80.3 \\
Ferrous and non-ferrous metals & $1,611.6$ & $-3,535.5$ & 119.2 & 82.3 \\
Engineering products & $11,685.5$ & $-22,779.1$ & 112.0 & 84.0 \\
Other product groups & $2,831.0$ & $-4,808.3$ & 130.4 & 83.3 \\
Imports - total & $23,167.3$ & $-44,372.8$ & 119.5 & \\
\hline
\end{tabular}

Source: author's calculations on the basis of Rosstat's data (Rosstat, 2017).

and imports. In such circumstances, there have been introduced anti-Russian sanctions which were consistently expanded and tightened. The combined effect of these factors contributed to a reduction in the Russian imports both in absolute and relative terms (Tables 1 and 2).

In absolute terms, the volume of imports of machine-building products decreased the most in 2014-2016. In second place were food and raw materials, which was largely the result of Russia's actions in response to the sanctions imposed against it. In the third place - was the decline of petrochemical products. In absolute terms, the volume of import of fuel and energy products decreased the least. However, in the last case, the rate of reduction was higher than that of other commodity groups (see Table 1). As a result, their lowest share in total imports in 2001 and
2013, became even smaller in 2016 (Table 3). The structure of imports by commodity groups under consideration in 2016 differs from the structure in 2013: the coefficient of relative structural changes is equal to $0.0602^{1}$.

In the regional aspect, five regions of the Russian Federation increased import volumes in 2014-2016. These are the Republic of Altay, the Republic of Ingushetia, the Chechen Republic, the Sakhalin Region and Yamal-Nenets Autonomous Area. Their combined share in the total volume

${ }^{1}$ The linear coefficient of relative structural shifts $\left(k_{\mathrm{s}, \mathrm{t}}\right)$ is calculated as the sum of the absolute value of differences of shares of elements of these structures $\left(d_{\mathrm{j}}\right)$ at the time point $\mathrm{t}-1$ and $\mathrm{t}: \mathrm{k}_{\mathrm{s}, \mathrm{t}}=\Sigma_{\mathrm{i}}\left|d_{\mathrm{i}, \mathrm{t}}-d_{\mathrm{i}, \mathrm{t}-1}\right|$. This coefficient varies in the range from zero to two and allows us to determine the average difference in the specific weights of parts of the whole at the considered points of time. The closer the coefficient is to zero, the less the structure has changed (Kazinets, 1981). 
Table 3

Shares of some product groups in the total volume of the Russian's imports in 2001-2016, \%

\begin{tabular}{lccc}
\hline \multicolumn{1}{c}{ Commodity group } & 2001 & 2013 & 2016 \\
\hline Food and raw materials & 24.51 & 13.66 & 13.72 \\
Production of fuel and energy complex & 2.75 & 1.15 & 0.84 \\
Petrochemical complex products & 20.18 & 15.90 & 18.56 \\
Wood and its products & 3.51 & 2.11 & 1.86 \\
Ferrous and non-ferrous metals & 7.18 & 6.98 & 6.26 \\
Engineering products & 37.94 & 48.96 & 47.23 \\
Other product groups & 3.93 & 11.24 & 11.53 \\
Imports - total & 100.0 & 100.0 & 100.0 \\
\hline
\end{tabular}

Source: author's calculations.

Table 4

Ten administrative entities of the Russian Federation with the most significant reduction in imports from non-CIS countries in 2014-2016

\begin{tabular}{|c|c|c|c|c|}
\hline \multirow{2}{*}{$\begin{array}{l}\text { Administrative entities of the } \\
\text { Russian Federation }\end{array}$} & \multicolumn{2}{|c|}{ Decrease in imports } & \multirow{2}{*}{$\begin{array}{l}\text { The coefficient } \\
\text { of consensus, in } \\
\text { fractions of a unit }\end{array}$} & \multirow{2}{*}{$\begin{array}{l}\text { The share of the region* } \\
\text { in the total volume } \\
\text { of the Russian imports } \\
\text { in } 2016, \%\end{array}$} \\
\hline & $\begin{array}{l}\text { Bln US } \\
\text { dollars }\end{array}$ & $\%$ & & \\
\hline Moscow city & $-53,032$ & -43.5 & 0.776 & 43.1 \\
\hline Sankt-Petersburg city & $-14,101$ & -40.5 & 0.200 & 12.4 \\
\hline Moscow Region & $-11,414$ & -39.9 & 0.158 & 10.6 \\
\hline Primorsky Krai & $-5,290$ & -62.4 & 0.118 & 1.9 \\
\hline Kaliningrad Region & $-6,121$ & -52.5 & 0.106 & 3.5 \\
\hline Kaluga Region & $-3,289$ & -45.5 & 0.050 & 2.4 \\
\hline Bryansk Region & $-0,896$ & -81.9 & 0.041 & 0.1 \\
\hline Leningrad Region & $-2,340$ & -47.1 & 0.037 & 1.6 \\
\hline Magadan Region & $-0,410$ & -89.5 & 0.032 & 0.03 \\
\hline Krasnodar Krai & $-1,970$ & -38.6 & 0.027 & 1.9 \\
\hline
\end{tabular}

Source: author's calculations.

* The terms "region", “administrative entity of the Russian Federation", and "subject of the Russian Federation" in this work are used as synonyms.

of Russian imports in 2016 was 3.8\%. In 43 of 82 subjects of the Russian Federation from the studied imports of at least one of the product groups in 2016 was more than in 2013.

However, the assessment of the significance of the decrease in imports (relative significance) for a particular administrative-territorial entity does not necessarily coincide with the assessment of the significance (relative significance) of such a decrease for the country as a whole. For example, in 2016 the volume of imports of the Kaliningrad Region was less by $52.5 \%$, and Moscow city by $43.5 \%$ less than, accord- ingly, in 2013. It seems that a decrease in the import's volume in the Kaliningrad Region was more significant than in Moscow city. However, in relative terms, the decline in Moscow's imports amounted to $42.4 \%$ of the total decrease in the country's imports, and the Kaliningrad region - only $4.6 \%$.

Therefore, for the Russian Federation as a whole, the decrease in Moscow city imports was more significant than the decrease in the Kaliningrad Region. Another example. The shares of the decrease in imports of the Kostroma Region and the Jewish Autonomous Region in the total 
Table 5

Ten administrative entities of the Russian Federation, whose imports from non-CIS countries increased in 2014-2016

\begin{tabular}{lcc}
\hline \multicolumn{1}{c}{$\begin{array}{c}\text { Administrative entities of the } \\
\text { Russian Federation }\end{array}$} & $\begin{array}{c}\text { Increase in imports, mln US } \\
\text { dollars }\end{array}$ & $\begin{array}{c}\text { The share of the region in the total } \\
\text { volume of the Russian imports } \\
\text { in 2016,\% }\end{array}$ \\
\hline Yamal-Nenets Autonomous Area & $4,781.7$ & 3.12 \\
Sakhalin Region & 508.5 & 1.04 \\
Kursk Region & 84.7 & 0.18 \\
Tyumen Region less autonomous & 80.8 & 0.32 \\
areas & & \\
Vologda Region & 25.5 & 0.31 \\
Chechen Republic & 14.7 & 0.02 \\
Republic of Tuva & 4.0 & 0.00 \\
Republic of Altay & 2.9 & 0.01 \\
Republic of Ingushetia & 2.5 & 0.01 \\
Kamchatka Territory & 2.1 & 0.05 \\
\hline
\end{tabular}

Source: author's calculations.

volume of a decrease in the Russian imports in $2015-2016$ coincide and were equal to $0.041 \%$. At the same time, imports of the Kostroma Region fell by $26.5 \%$, and imports of the Jewish Autonomous Region - by $67.7 \%$. Therefore, with the same significance for the country decrease in the Jewish Autonomous Region was more significant than in the Kostroma Region.

For joint accounting and coherence of the significance of reducing the value of some indicator for the country and the region we propose to calculate the coefficient of consensus $\mathrm{k}_{\mathrm{i}, \mathrm{t}}$ :

$$
\mathrm{k}_{\mathrm{i}, \mathrm{t}}=\left(d_{\mathrm{i}, \mathrm{t}} \times v_{\mathrm{i}, \mathrm{t}-1}\right) /\left(d_{\mathrm{t}} \times v_{\mathrm{i}, \mathrm{t}}\right) .
$$

Here, in the general case:

$i$-index of indicators, $\mathrm{i}=1,2, \ldots, \mathrm{n}$;

$t$ - time points, $\mathrm{t}=1,2, \ldots, \mathrm{T}$;

$v_{\mathrm{i}, \mathrm{t}}-$ the value of the index $i$ at the point of time $t$;

$d_{\mathrm{i}, \mathrm{t}}=v_{\mathrm{i}, \mathrm{t}}-v_{\mathrm{i}, \mathrm{t}-1}-$ change in the value of indicator $i$ between the time point $t-1$ and the time point $t$;

$d_{\mathrm{t}}=\Sigma_{\mathrm{i}} d_{\mathrm{i}, \mathrm{t}}-$ total change of values of all indicators $i$ between the time point $t-1$ and the time point $t$.

In the study of the growth of the values of the indicators, the formula for calculating the consensus coefficient has the form:

$$
\mathrm{k}_{\mathrm{i}, \mathrm{t}}=\left(d_{\mathrm{i}, \mathrm{t}} \times v_{\mathrm{i}, \mathrm{t}}\right) /\left(d_{\mathrm{t}} \times v_{\mathrm{i}, \mathrm{t}-1}\right) .
$$

The higher the value of the consensus coefficient, the more significant is the change in the studied indicator for the country and for the particular region.

On the basis of the analysis of values of the proposed consensus coefficient, in 2014-2016 the most significant was the decrease in the volume of imports from so-called "far-abroad" countries ${ }^{2}$, of the ten subjects of the Russian Federation presented in Table 4.

In 2016, these ten regions accounted for $77.5 \%$ of Russia's total imports from "far-abroad" countries in particular for Moscow city, Sankt-Petersburg city and the Moscow Region - 66\%. However, among these three regions, imported goods are "internally exported" by the importing firms and numerous intermediaries to other regions of the country. The exception by virtue of its geographical position is only the Kaliningrad Region.

Despite the overall decrease in the value of imports by the Russian Federation in 2014-2016 as a whole, its value increased in ten administrative entities of the Russian Federation (Table 5). However, their aggregate share in the total volume of imports of the whole country in 2016 was only $5 \%$, and $4 \%$ of it concerns both the Yamal-Nenets Autonomous Area and the Sakhalin Region.

\footnotetext{
${ }^{2}$ In Russia so-called "far-abroad" countries means all countries (states) except those that came out of the USSR, were they were the Union Republics.
} 
Table 6

Shares of some product groups in the total volume of the Russian exports in 2001-2016, \%

\begin{tabular}{|c|c|c|c|}
\hline Commodity group & 2001 & 2013 & 2016 \\
\hline Food and raw materials & 1.55 & 3.08 & 5.97 \\
\hline Production of fuel and energy complex & 54.65 & 70.67 & 58.18 \\
\hline Petrochemical complex products & 7.15 & 5.84 & 7.29 \\
\hline Wood and its products & 4.47 & 2.08 & 3.43 \\
\hline Ferrous and non-ferrous metals & 14.35 & 7.77 & 10.08 \\
\hline Engineering products & 10.09 & 5.39 & 8.55 \\
\hline Other product groups & 7.74 & 5.17 & 6.50 \\
\hline Exports - total & 100.0 & 100.0 & 100.0 \\
\hline
\end{tabular}

Source: author's calculations on the basis of Rosstat's data (Rosstat, 2017).

Table 7

Volumes of the Russian exports of some commodity groups in 2001-2016, mln US dollars

\begin{tabular}{lccc}
\hline \multicolumn{1}{c}{ Commodity group } & $\mathbf{2 0 0 1}$ & $\mathbf{2 0 1 3}$ & 2016 \\
\hline Food and raw materials & $1,472.3$ & $16,196.1$ & $17,057.2$ \\
Production of fuel and energy complex & $52,074.9$ & 371,792 & $166,170.3$ \\
Petrochemical complex products & $6,815.2$ & $30,739.2$ & $20,813.6$ \\
Wood and its products & $4,255.3$ & $10,965.4$ & $9,804.8$ \\
Ferrous and non-ferrous metals & 13,673 & $40,859.1$ & $28,793.3$ \\
Engineering products & $9,161.4$ & $28,339.1$ & $24,415.1$ \\
Other product groups & $7,374.5$ & $27,221.4$ & $18,565.5$ \\
Exports - total & 95281.6 & 526112.3 & 285619.8 \\
\hline
\end{tabular}

Source: author's calculations on the basis of Rosstat's data (Rosstat, 2017).

Table 8

Average annual change in volumes of the Russian's export in 2002-2013 and in 2014-2016

\begin{tabular}{|c|c|c|c|c|}
\hline \multirow{2}{*}{ Commodity group } & \multicolumn{2}{|c|}{$\begin{array}{l}\text { Annual average absolute change } \\
\text { in volume, } \mathrm{mln} \text { US dollars }\end{array}$} & \multicolumn{2}{|c|}{ Average annual rate of change, $\%$} \\
\hline & $2002-2013$ & $2014-2016$ & $2002-2013$ & 2014-2016 \\
\hline Food and raw materials & $1,227.0$ & 287.0 & 122.1 & 101.7 \\
\hline Production of fuel and energy & $26,643.1$ & $-68,540.6$ & 117.8 & 76.5 \\
\hline complex & $1,993.7$ & $-3,308.5$ & 113.4 & 87.8 \\
\hline Petrochemical complex products & 559.2 & -386.9 & 108.2 & 96.3 \\
\hline Wood and its products & $2,265.5$ & $-4,021.9$ & 109.6 & 89.0 \\
\hline Ferrous and non-ferrous metals & $1,560.2$ & $-1,308.0$ & 109.4 & 95.2 \\
\hline Engineering products & $1,653.9$ & -288.5 & 111.5 & 88.0 \\
\hline Other product groups & $35,902.6$ & $-80,164.2$ & 115.3 & 81.6 \\
\hline Exports - total & & & & \\
\hline
\end{tabular}

Source: author's calculations on the basis of Rosstat's data (Rosstat, 2017). 
Summing up the interim results, we can say that the systemic effect of the unfavourable geopolitical situation for Russia, anti-Russian sanctions, and the Russian counter-sanctions imposed in response to them, as well as the economic recession in the country in 2015-2016, naturally led to a decrease in the volume of the Russian imports.

\section{Changes in the Volume and Structure of the Russian Exports}

By the time of the introduction of anti-Russian sanctions by President Barack Obama, the share of fuel and energy products in the total volume of Russian exports exceeded $70 \%$ (Table 6). The sanctions were aimed primarily at the financial, fuel and energy, defence, scientific and technological sectors of the Russian economy ${ }^{3}$. Therefore, it can be assumed that all other things being equal, the anti-Russian sanctions have contributed to the reduction of exports of Russian fuel and energy products. In 2014-2016 exports of this particular commodity group fell most strongly in both absolute and relative terms (Tables 7 and 8).

In the second place, in absolute and relative terms, decrease concerned the export of petrochemical products, and in the third place - engineering products. Many companies in these sectors of the economy are until now the subjects of the anti-Russian sanctions adopted in March 2014 and consistently expanded. Exports of wood and wood products decreased the least. Russia's response to the sanctions imposed by the group of countries was primarily aimed to support the domestic agricultural producers and a ban on the import of a number of food products from countries that have adopted anti-Russian sanctions. As a result, this contributed to the increase in the volume of Russian exports of food products and raw materials.

The difference in the rate of change in the volume of exports of the main commodity groups led to a change in the commodity structure of the Russian exports (Table 6). Taking into account the value of the linear coefficient of relative structural changes (0.2498), the structure of exports of analysed product groups in 2016 was almost a quarter different from the structure of 2013. The share of exports of fuel and energy products has decreased.

\footnotetext{
${ }^{3}$ From March 2014 to August 2017, the United States introduced restrictive measures against 244 companies, organizations and banks and 172 individuals.
}

However, the decrease was compensated by the growth of shares of all other product groups.

In the regional context, 16 administrative entities of the Russian Federation (out of 82 studied) increased their exports in 2014-2016. However, it did not have a significant impact on the total volume of exports, since their aggregate share in the Russian exports in 2016 was only $2.5 \%$. The number of regions that increased the volume of exports of at least one of the product groups is much larger (Table 9). In 2014-2016 only ten regions did not increase the volume of exports of any of the commodity groups presented in Tables 7-8. These are the Republic of Bashkortostan, the Republic of Mari El, the Karachay-Cherkess Republic, the Perm region, also the Volgograd, Voronezh, Irkutsk, Leningrad, Novgorod, and Chelyabinsk regions. Their aggregate share in the total volume of exports of the country as a whole was not significant; in 2016 it was equal to $9.7 \%$.

In the regional aspect, in 2014-2016, the volume of exports to "far-abroad" countries decreased by 59 of the 82 subjects of the Russian Federation. The total share of exports of ten of them with the highest values of the consensus coefficient $\mathrm{k}_{\mathrm{i}, \mathrm{t}}$ in the total volume of exports of the Russian Federation to "far-abroad" countries in 2016 was $60.1 \%$ (Table 11). It is easy to see that eight of them are oil-producing regions, and Moscow city is an exporter of crude oil and oil products ${ }^{4}$. No doubt, it was a consequence of the above-described fall in revenue from oil sales caused by declining oil prices.

The volume of exports to "far-abroad" countries has decreased in 23 subjects of the Russian Federation. Among them, there are also three oil-producing regions (the Novosibirsk region, the Republic of Dagestan and the Chechen Republic), but their share in total oil production in Russia is not large. The aggregate share of these 23 regions in the total volume of the Russian exports in 2016 was only $2.7 \%$.

Thus, the fall in prices on the world energy markets led not only to a decrease in foreign currency earnings from oil and gas exports received by the Russian Federation in 2014-2016 but also contributed to a reduction in the volume of exports of oil and gas producing regions.

\footnotetext{
${ }^{4}$ The Federal Service of State Statistics (Rosstat) provides data on exports and imports of subjects of the Russian Federation in accordance with the place of registration of the owner of the goods, and not the regions of its activities (production of exported goods, consumption of imported goods).
} 
Table 9

Shares of the first three regions of the Russian Federation with the largest increase in the volumes of exports of commodity groups in the total increase in the volume of exports of these commodity groups from Russia in 2014-2016, \%

\begin{tabular}{|c|c|c|c|}
\hline $\begin{array}{l}\text { Administrative entities of the Russian } \\
\text { Federation }\end{array}$ & Share,\% & $\begin{array}{l}\text { Administrative entities of the Russian } \\
\text { Federation }\end{array}$ & Share,\% \\
\hline \multicolumn{2}{|l|}{ Food and raw materials } & \multicolumn{2}{|l|}{ Ferrous and non-ferrous metals } \\
\hline Rostov Region & 27.8 & Murmansk Region & 33.8 \\
\hline Kaliningrad Region & 12.0 & Krasnodar Krai & 16.9 \\
\hline Murmansk Region & 7.3 & Kaluga Region & 15.8 \\
\hline Total & 47.1 & Total & 66.5 \\
\hline Products of fuel and energy complex & & Engineering products & \\
\hline Stavropol Krai & 32.9 & Moscow city & 44.0 \\
\hline Kaluga Region & 19.8 & Sverdlovsk Region & 17.4 \\
\hline Bryansk Region & 19.3 & Khabarovsk Krai & 10.4 \\
\hline Total & 72.0 & Total & 71.8 \\
\hline Petrochemical complex products & & Other products & \\
\hline Rostov Region & 49.0 & Arkhangelsk Region & 36.0 \\
\hline Novosibirsk Region & 14.1 & Khabarovsk Krai & 8.8 \\
\hline Krasnodar Krai & 12.1 & Rostov Region & 6.9 \\
\hline Total & 75.2 & Total & 51.7 \\
\hline Wood and its products & & The total increase in exports & \\
\hline Sankt-Petersburg city & 45.5 & Murmansk Region & 28.5 \\
\hline Republic of Tatarstan & 13.0 & Novosibirsk Region & 28.2 \\
\hline Smolensk Region & 8.4 & Republic of Tuva & 12.7 \\
\hline Total & 66.9 & Total & 69.4 \\
\hline
\end{tabular}

Source: author's calculations on the basis of Rosstat's data (Rosstat, 2017).

Table 10

Shares of the first three regions of the Russian Federation with the largest decrease in the volumes of exports of commodity groups in the total decrease in the volume of exports of these commodity groups from Russia in 2014-2016, \%

\begin{tabular}{lclc}
\hline $\begin{array}{c}\text { Administrative entities of the Russian } \\
\text { Federation }\end{array}$ & Share, \% & \multicolumn{1}{c}{$\begin{array}{c}\text { Administrative entities of the Russian } \\
\text { Federation }\end{array}$} & Share, \% \\
\hline \multicolumn{1}{c}{ Food and raw materials } & \multicolumn{1}{c}{ Ferrous and non-ferrous metals } \\
\hline $\begin{array}{l}\text { Sankt-Petersburg city } \\
\text { Moscow Region }\end{array}$ & 16.4 & Krasnoyarsk Krai & 19.4 \\
Moscow city & 12.8 & Sverdlovsk Region & 10.6 \\
Total & 9.7 & Lipetsk Region & 10.2 \\
Products of fuel and energy complex & 38.9 & Total & 40.2 \\
Moscow city & & Engineering products & \\
Tyumen Region & 50.9 & Samara Region & 13.5 \\
Khanty-Mansi Autonomous Area - Yugra & 9.8 & Republic of Tatarstan & 12.8 \\
Total & 6.3 & Moscow Region & 9.9 \\
Petrochemical complex products & 67.0 & Total & 36.2 \\
Moscow city & & Other products & 45.3 \\
Samara Region & 15.0 & Moscow city & 10.7 \\
Republic of Tatarstan & 12.3 & Sankt-Petersburg city & 6.8 \\
Total & 10.3 & Belgorod Region & 62.8 \\
Wood and its products & 37.6 & Total & \\
Irkutsk Region & & The total decrease in exports \\
Republic of Karelia & 24.9 & Moscow city & 45.6 \\
Perm Krai & 13.9 & Tyumen Region without autonomous areas & 8.4 \\
Total & 12.3 & Republic of Tatarstan & 5.4 \\
\hline
\end{tabular}

Source: author's calculations on the basis of Rosstat's data (Rosstat, 2017). 
Table 11

Ten administrative entities of the Russian Federation with the largest decrease in the volume of exports in 2014-2016

\begin{tabular}{|c|c|c|c|c|}
\hline \multirow{2}{*}{$\begin{array}{l}\text { Administrative entities of the } \\
\text { Russian Federation }\end{array}$} & \multicolumn{2}{|c|}{ Decrease } & \multirow{2}{*}{$\begin{array}{l}\text { The coefficient } \\
\text { of consensus, in } \\
\text { fractions of a unit }\end{array}$} & \multirow{2}{*}{$\begin{array}{l}\text { The share of the } \\
\text { region in the } \\
\text { Russian export, \% }\end{array}$} \\
\hline & $\begin{array}{l}\text { bln. US } \\
\text { dollars }\end{array}$ & $\begin{array}{l}\text { Percentage } \\
\text { points }\end{array}$ & & \\
\hline Tyumen Region & $-18,885$ & -90.7 & 0.990 & 0.8 \\
\hline Moscow city & $-93,955$ & -46.9 & 0.962 & 42.6 \\
\hline Republic of Tatarstan & $-12,097$ & -59.9 & 0.147 & 3.2 \\
\hline Leningrad Region & $-8,662$ & -65.9 & 0.124 & 1.8 \\
\hline $\begin{array}{l}\text { Khanty-Mansi Autonomous } \\
\text { Area - Yugra }\end{array}$ & $-12,097$ & -51.9 & 0.123 & 4.5 \\
\hline Republic of Bashkortostan & $-7,706$ & -61.3 & 0.097 & 2.0 \\
\hline Sakhalin Region & $-8,010$ & -47.7 & 0.075 & 3.6 \\
\hline Komi Republic & $-2,554$ & -78.5 & 0.058 & 0.3 \\
\hline Samara Region & $-3,822$ & -61.1 & 0.048 & 1.0 \\
\hline Volgograd Region & $-2,137$ & -73.7 & 0.040 & 0.3 \\
\hline
\end{tabular}

Source: author's calculations on the basis of Rosstat's data (Rosstat, 2017).

Table 12

Geographical structure of foreign trade of the Russian Federation in 2000-2016,\%

\begin{tabular}{ccccc}
\hline \multirow{2}{*}{ Year } & $\begin{array}{c}\text { Russia } \\
\text { total }\end{array}$ & $\begin{array}{c}\text { CIS } \\
\text { countries }\end{array}$ & $\begin{array}{c}\text { Which have introduced the } \\
\text { anti-Russian sanctions* }\end{array}$ & $\begin{array}{c}\text { Which have not introduced } \\
\text { the anti-Russian sanctions }\end{array}$ \\
\cline { 4 - 5 } 2000 & 100.0 & 34.3 & 61.4 & \\
2013 & 100.0 & 13.6 & 55.6 & 4.3 \\
2016 & 100.0 & 10.7 & 52.4 & 30.8 \\
& & & Exports & 36.9 \\
2000 & 100.0 & 13.4 & 66.4 & 20.2 \\
2013 & 100.0 & 15.0 & 66.9 & 18.1 \\
2016 & 100.0 & 13.2 & 56.5 & 30.3 \\
& & & Trade turnover & \\
2000 & 100.0 & 18.6 & 65.1 & 16.3 \\
2013 & 100.0 & 14.4 & 62.4 & 32.2 \\
2016 & 100.0 & 12.3 & 54.9 & 32.8 \\
\hline
\end{tabular}

Source: author's calculations on the basis of Rosstat's data (Rosstat, 2017).

* Ukraine is included in this work in the number of "far-abroad" countries that have declared anti-Russian sanctions.

The geographical structure of foreign trade of the Russian Federation in the conditions of anti-Russian sanctions

It is natural to expect that if a country or a group of countries for some reason limits foreign trade relations, scientific, technical, cultural, educational, and other relations with a certain country (let's call it the implementation of hostile poli- cies), the latter will seek to shift to friendly-oriented states and develop relations with them. At the same time, its trade and other relations with countries engaged in hostile policies will, by virtue of the actions of the latter, weaken.

This is what the economic agents in regions of the Russian Federation have done in the conditions of the anti-Russian sanctions. They have 
Table 13

Ten of the countries that have established anti-Russian sanctions, in which in 2014-2016 the volume of exports from the Russian Federation was most severely reduced

\begin{tabular}{|c|c|c|c|c|}
\hline \multirow[b]{2}{*}{ Country } & \multicolumn{2}{|c|}{ Decrease } & \multirow{2}{*}{$\begin{array}{l}\text { The coefficient } \\
\text { of consensus, } \\
\text { in fractions of a unit }\end{array}$} & \multirow{2}{*}{$\begin{array}{l}\text { Share in Russia's exports } \\
\text { to countries } \\
\text { that have imposed sanctions } \\
2016, \%\end{array}$} \\
\hline & $\begin{array}{l}\text { mln US } \\
\text { dollars }\end{array}$ & $\begin{array}{l}\text { percentage } \\
\text { points }\end{array}$ & & \\
\hline The Netherlands & $-40,845$ & -58.3 & 0.520 & 18.1 \\
\hline Italy & $-26,805$ & -69.1 & 0.461 & 7.4 \\
\hline Ukraine & $-17,471$ & -73.4 & 0.349 & 3.9 \\
\hline Germany & $-15,797$ & -42.6 & 0.146 & 13.2 \\
\hline United Kingdom & $-9,505$ & -57.8 & 0.120 & 4.3 \\
\hline Poland & $-10,442$ & -53.3 & 0.119 & 5.7 \\
\hline Japan & $-10,307$ & -52.4 & 0.115 & 5.8 \\
\hline $\begin{array}{l}\text { Swiss } \\
\text { Confederation }\end{array}$ & $-5,711$ & -65.4 & 0.088 & 1.9 \\
\hline Finland & $-6,770$ & -50.9 & 0.073 & 4.0 \\
\hline Spain & $-4,082$ & -67.7 & 0.670 & 1.2 \\
\hline
\end{tabular}

Source: author's calculations on the basis of 'Sanctions against Russia' (2018) and Rosstat (2017).

Table 14

Ten of the countries that have established anti-Russian sanctions, in which in 2014-2016 the volume of imports from the Russian Federation was the most severely reduced

\begin{tabular}{lcccc}
\hline \multicolumn{1}{c}{ Country } & \multicolumn{2}{c}{ Decrease } & \begin{tabular}{c} 
The coefficient \\
of consensus, \\
\cline { 2 - 3 } in fractions of a unit
\end{tabular} & $\begin{array}{c}\text { The share of imports } \\
\text { from Russia in 2016, \% }\end{array}$ \\
\cline { 2 - 4 } Ukraine* & $-11,902$ & -75.4 & 0.513 & 4.1 \\
Germany & $-18,463$ & -48.7 & 0.382 & 20.4 \\
Japan & $-6,884$ & -50.7 & 0.149 & 7.0 \\
Italy & $-6,716$ & -46.1 & 0.133 & 8.2 \\
United Kingdom & $-4,682$ & -57.7 & 0.118 & 3.6 \\
Poland & $-4,367$ & -52.5 & 0.098 & 4.1 \\
USA & $-5,835$ & -35.3 & 0.096 & 11.2 \\
France & $-4,522$ & -34.8 & 0.074 & 8.9 \\
Finland & $-2,918$ & -54.0 & 0.067 & 2.6 \\
The Netherlands & $-2,835$ & -48.4 & 0.058 & 3.2 \\
\hline
\end{tabular}

Source: author's calculations on the basis of 'Sanctions against Russia' (2018) and Rosstat (2017).

* On March 21, 2018, the Cabinet of Ministers of Ukraine decided to terminate the Program of economic cooperation with Russia. This program "was approved by the parties in 2011 and is designed for the period up to 2020. It provides for cooperation between the two countries in various fields, including trade, transport, resort and recreational area, social and humanitarian matters, border territories, and a number of others" (The Cabinet of Ministers, 2018). 
changed the structure of foreign trade in favour of "far-abroad" countries that have not joined the hostile policy of the United States, the European Union and the countries that support them (Table 12). It should be noted that with regard to imports, such a reorientation is due to a number of reasons (in particular, the Jackson-Vanik amendment, the so-called "Magnitsky List", hostile actions carried out by foreign States after E. J. Snowden's arrival in the Russian Federation) was held for a long time.

Despite the decrease in the volume of foreign trade turnover with countries which established the anti-Russian sanctions, the country's structure of exports from the Russian Federation in these countries in 2016 has little changed as compared to 2013. Even less has changed the structure of the Russian imports from these countries (Figure 2). This means that the main partners of Russia in the sphere of foreign trade among the countries that have adopted anti-Russian sanctions remained the same. The top five countries with the greatest turnover in trade with the Russian Federation in 2013 were the Netherlands, Germany, Italy, Ukraine, and Japan (their aggregate share in trade with all countries of the anti-Russian coalition was 51.4\%), and in 2016 were Germany, the Netherlands, the USA, Italy, and Japan (50.1\% share).

In 2016, the volume of Russian exports to 32 of the 42 states announced in 2014 the anti-Russian sanctions were less than in 2013. For two countries the Republic of Slovenia and Montenegro exports from Russia remained at the level of 2013. For seven countries (Bulgaria, Luxembourg, Portugal, Romania, Albania, Iceland and Liechtenstein) it increased. Their aggregate share in the total volume of the Russian exports to countries that apply sanctions against Russia was not large in 2016 - only 3.06\%. And for one country - the Republic of Moldova - data on the size of foreign trade could not be found.

Table 13 shows a dozen countries with the most significant decrease in the Russian exports. In 2016, the share of exports from the Russian Federation to these ten countries was $65.5 \%$ of Russia's exports to countries that have imposed sanctions.

In 2016, the volume of imports of the Russian Federation from 40 countries, applied the antiRussian sanctions, was less than in 2013. Imports from the Republic of Albania remained at the same level. For the Republic of Moldova, there is no data. Ten countries, of which Russian imports fell most significantly, are shown in Table 14.

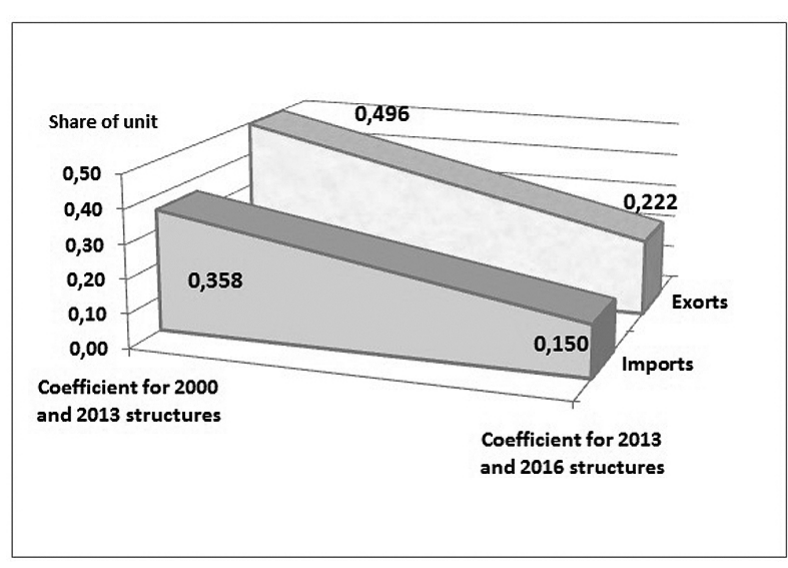

Figure 2. The values of the coefficient of relative structural changes for compared export structures

of the Russian Federation to the countries that have established anti-Russian sanctions and for the structures of the Russian imports from these countries in 2000 and 2013, and in 2013 and 2016.

Source: the author.

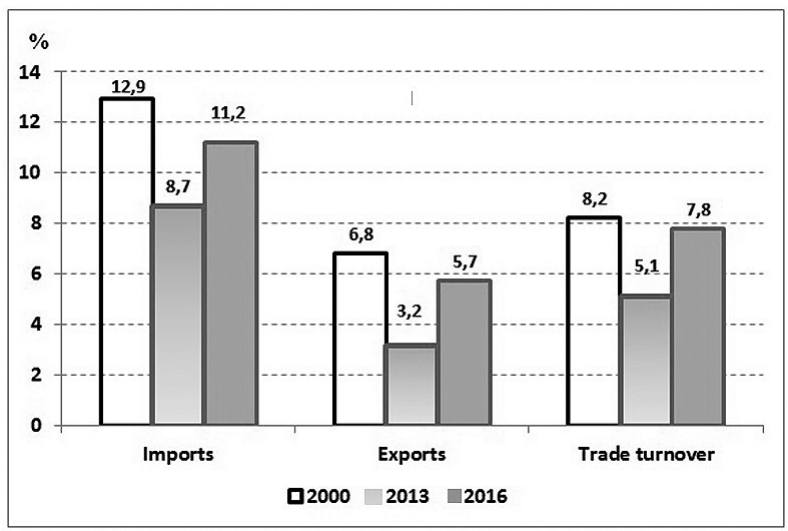

Figure 3. The share of the USA in the total volume of Russia's foreign trade with the countries of the antiRussian coalition in 2000-2016,\%.

Source: author's calculations on the basis of Rosstat's data (Rosstat, 2017).

The share of imports from countries listed in Table 14 in the total volume of imports from the Russian Federation in the states in which anti-Russian sanctions are in force in 2016 was $73.3 \%^{5}$.

\footnotetext{
${ }^{5}$ In sixth place according to the value of the coefficient of the consensus was the Principality of Liechtenstein. The volume of its imports from Russia fell by $97 \%$. However, the scale of reduction was small ( -291 million dollars), and the share of the Principality in the total volume of imports of states that established anti-Russian sanctions in 2016 was only $0.01 \%$. In nine countries, we observed the decrease of the Russian imports less in absolute terms than in Liechtenstein, and the share of import from Russia, compared with that in Lichtenstein, was only in two of them. Hence, the Principality of Liechtenstein was not included in Table 14.
} 
Table 15

Aircraft fleet of the largest airlines in Russia, units

\begin{tabular}{ccccc}
\hline Aircraft & $\begin{array}{c}\text { Aeroflot } \\
\text { July 2018 }\end{array}$ & $\begin{array}{c}\text { S 7 Airlines } \\
\text { July 2018 }\end{array}$ & $\begin{array}{c}\text { UTair } \\
\text { July 2018 }\end{array}$ & $\begin{array}{c}\text { Rossiya Airlines } \\
\text { July 2018 }\end{array}$ \\
\hline \multirow{2}{*}{ Boeing } & 58 & Foreign & & \\
Airbus & 138 & 21 & 53 & 37 \\
Embraer & 0 & 50 & 0 & 31 \\
ATR & 0 & 17 & 0 & 0 \\
& 45 & 0 & 15 & 0 \\
& Russian & & 9 \\
& SSJ-100 (Sukhoi & 0 & Aн-74, AH-74 TK-100, & Aн-2 \\
\hline
\end{tabular}

Source: compiled by the author according to the airline websites.

What about trade between the Russian Federation and the United States, the main initiator of antiRussian sanctions? In terms of the reduction of the Russian exports to the United States in 2014-2016, they were on the 23rd place out of 32. The Russian export to this country decreased by 1844 million dollars or $16.6 \%$. At the same time, their share in the total volume of the Russian exports to the countries of the anti-Russian coalition increased from $3.2 \%$ in 2013 to $5.7 \%$ in 2016 (Figure 3).

One of the reasons is that by introducing all sorts of restrictive measures, the government and large US corporations strictly observe their own interests: they do not prohibit or restrict trade with the goods in which they themselves are in dire need or in the export of which they are interested ${ }^{6}$. Here, for example, with what care the Countering America's Adversaries Through Sanctions Act (HR 3364) prescribes an exception to the number of sanctioned goods relating to activities of the National Aeronautics and Space Administration.

"Nothing in this Act or the amendments made by this Act shall be construed to authorize the imposition of any sanction or other condition, limitation, restriction, or prohibition, that directly or indirectly impedes the supply by any entity of the Russian Federation of any product or service, or the procurement of such product or service by any contractor or subcontractor of the United States or any other entity, relating to or in connection with any space launch conducted for (1) the Na-

\footnotetext{
${ }^{6}$ According to the President of the American Chamber of Commerce in Russia Alexis Rodzianko, "American sanctions affect areas in which trade exchange was previously small, for example, military products" (Spigel, 2015).
}

tional Aeronautics and Space Administration; or (2) any other non-Department of Defense customer" (HR 3364, 2017, Sec. 237, (b)).

There is no ban on goods that are profitable for Western countries to export to the Russian Federation. In addition, on the Russian market successfully operate well-known American companies and their branches: "Procter \& Gamble”, "Apple”, "PepsiCo", "Mars”, “Coca-Cola”, "McDonald's”, “Johnson \& Johnson”, “Cargill”, “International Paper”. In 2016, the total revenue of these 10 companies in Russia amounted to 864 billion rubles. It was equal to $6.4 \%$ of the revenues of the federal budget of the Russian Federation or to $9.0 \%$ of the volume of shipped products made exclusively in enterprises of the Russian form of ownership. Neither the US nor the EU has sanctions against exports to Russia of cars, civil aircraft, medicines and some other goods.

The size of the decrease in the volume of the Russian imports from the United States, the latter is also not the first, but only in seventh place. One of the reasons - they are less than the main European countries affected by the response of the Russian Federation. In addition, it also involves a) the interests of large corporations and b) the desire to keep the Russian Federation in a state of technological dependence ${ }^{7}$.

The acquisition of high-tech products and technologies in the foreign market reduces the incentives of the state and business to conduct their own expensive scientific and technical research, to develop,

\footnotetext{
7 "The degree of technological dependence is simply enormous. And it is much more than it follows from the general figures that we buy more than $\$ 100$ billion a year of machinery and equipment” [Klepach, 2015, p. 7].
} 
test and certify the high-tech and expensive products, such as: software, information technology, modern computer equipment, communications technology and electronic component base (primarily the spacemilitary level), medical equipment and medicines, 3D printing, genetic material, raw materials for the production of vaccines, seeds, etc.

As an example of import dependence, we take the aircraft fleet of the largest airlines of the Russian Federation. It is dominated by foreign-made aeroplanes (Table 15).

However, in the SSJ-100 aircraft (Sukhoi SuperJet-100) 85\% assembled components and assemblies come from "Airbus" and "Boeing" (Ivashov, 2017). Moreover, under the terms of the contract with Boeing and the lessors, Aeroflot is entitled to a 30\% discount, only in the absence of Russianmade aircraft in its aircraft. Hence, do not blame the "aggressive" policy of "Boeing" or "Airbus" in Russia - they penetrate to the extent that they are allowed.

The use of foreign-made aircraft, as well as any other foreign equipment, entails the need to import the necessary spare parts, repair equipment and software, as well as training of personnel abroad. As a result, the US share in the total volume of the Russian imports from states that have adopted the anti-Russian sanctions increased by 2.5 percentage points (pp), and in a trade with these states - by $2.7 \mathrm{pp}$.

Therefore, during the period under review, in the field of foreign trade with the Russian Federation, losses of the USA from the anti-Russian restrictions and Russia's response measures were less than many other states that supported sanctions against Russia. In 2016, the USA share in the structure of foreign trade of the Russian Federation with the countries of the anti-Russian coalition practically returned to the level of 2000 (Figure 2).

\section{Conclusions}

For many years, the United States and other foes of the USSR and the Russian Federation purposefully formed a group of potentially dangerous for the country's economy external factors (Sanctions against Russia, 2018). These include, in particular, technological, financial and import dependence on the Western countries and the oil and gas orientation of the economy and exports. The development on the basis of foreign technology, knowledge, know-how and technolo- gies required attracting foreign currency for their purchase. Principally, the currency came from the export of fuel and energy resources and other mineral resources. Imported technologies, machinery and materials were used for their extraction. The result was an emergence of a vicious circle - large-scale import of equipment and technologies required expanding the volume of sales of raw materials. To do this, it was necessary to increase the size of its production. That, in turn, required an increase in imports of equipment and other goods used for the extraction of mineral resources.

Payment for imports in foreign currency received as loans from foreign banks, put business and the state in dependence on the global financial and credit system, largely controlled and managed by the United States of America.

In addition, development of the USSR and Russia, through the import of equipment, technologies, purchase of foreign patents and licenses, contributed to the fact that the country as a whole, large and the largest firms and corporations reduced (up to complete cessation) their own research, development of innovations, the creation of testing laboratories and stands, etc. As a result, they not only found themselves in scientific, technological and financial dependence on the advanced development in science and technology states, public, and private corporations but fixed forever such dependence. At the same time, the scientific and technological gap did not remain at a fixed level but deepened over time.

Vladimir Putin in his message to the Federal Assembly said that "technological lag, dependence mean reduction of security and economic opportunities of the country, and as a result - loss of sovereignty" (President Putin's Message, 2018). At a convenient time, foes of the Russian Federation can use these time bombs.

The system of hostile external factors also includes restrictive financial and economic measures (sanctions), unfavorable conditions of the world energy markets, the use of unfair competition against Russia, the ill-grounded use of legal means, measures of political, cultural, scientific and technological isolation of the Russian Federation, information war organized against the country and its leadership.

Together, these factors have largely contributed to the reduction in the volume of foreign trade 
of the Russian Federation. At the same time, the dynamics of the Russian imports were higher than exports. The product and geographical structure of imports have changed less than that of exports. Consequently, the negative impact of the global economic environment, the anti-Russian sanctions and Russia's response measures on the dynamics and volumes of exports from the Russian Federation were stronger than the dynamics of change and the volume of imports.

\section{References}

HR 3364. Countering America's Adversaries through Sanctions Act. (2017). Retrieved from https://www.congress.gov/ bill/115th-congress/house-bill/3364/text.

Ivashov, L. G. (2017, August 10). Words, Words ...[Slova, slova...]. Zavtra, 32, 2. Retrieved from http://zavtra.ru/blogs/ authors/1923.

Kazinets, L. S. (1981). Growth rates and structural changes in the economy: (Indicators of planning and statistics) [Tempy rosta i strukturnye sdvigi v ekonomike (pokazateli planirovaniya i statistiki)]. Moscow: Ekonomika. $184 \mathrm{p}$.

Klepach, A. N. (2015). International sanctions and response: is positive for the Russian economy possible? [Mezhdunarodnye sanktsii i otvetnye mery: vozmozhen li pozitiv dlya rossiiskoi ekonomiki?]. Mir novoi ekonomiki = The world of the new economy, 1, 6-12.

President Putin’s Message. (2018). Retrieved from http://www.kremlin.ru/events/president/news/56957.

Rossiya Airlines. (2018, July 29). Retrieved from http://samolety.org/rossiya/.

Rosstat. (2017). Russian Statistical Yearbook, 2017 [Rossiiskii statisticheskii ezhegodnik, 2017]. http://www.gks.ru/wps/ wcm/connect/rosstat_main/rosstat/ru/statistics/publications/catalog/doc_1135087342078.

S 7 Airlines. (2018, July 29). In Wikipedia. Retrieved from https://ru.wikipedia.org/wiki/S 7_Airlines.

S 7 Airlines. Our Fleet. (2018, July 29). Retrieved from https://www.s7.ru/about/ourfleet.dot.

Aeroflot. (2018, July 29). Retrieved from https://www.aeroflot.ru/ru-ru/flight/plane_park.

Sanctions against Russia and international trade. (2018, January 27). Retrieved from https://cdn4.img.ria.ru/images/150970/03/1509700324.png.

Spiegel. (2015, June 2). The US “forget” about sanctions against Russia, when it is profitable for them. Retrieved from http://russian.rt.com/inotv/2015-05-31/Spiegel-SSHA-zabivayut-o-sankciyah.

The Cabinet of Ukraine broke the program of economic cooperation with Russia. (2018, July 27). Retrieved from http://tass.ru/ekonomika/5051911.

Utair. (2018, July 29). Retrieved from https://www.utair.ru/en/about/today/park/\#planes.

\section{Внешняя торговля России в условиях санкций}

\section{Сергей Казанцев}

Доктор экономических наук, Институт экономики и организации промышленного производства СО РАН, Новосибирск, Россия

kzn-sv@yandex.ru

Аннотация. Экспортно-сырьевая модель развития и высокая зависимость от внешнеэкономической конъюнктуры входят в число главных стратегических угроз экономической безопасности Российской Федерации. Поэтому не случайно ряд стран пытается реализовать эти угрозы для достижения своих геополитических целей и вводит разного рода ограничения, запреты и санкции. В статье представлены результаты анализа влияния антироссийских санкций на внешнюю торговлю России в 2014-2016 гг. Показано, что в сфере внешней торговли негативное воздействие запретов и санкций, а также неблагоприятных внешних и внутренних процессов и факторов сильнее чем в других секторах экономики отразилось на топливно-энергетическом, нефтехимическом и машиностроительном комплексах. Больше других их почувствовали субъекты Российской Федерации, в которых сосредоточены основные потоки экспорта и импорта, а также некоторые нефтегазодобывающие и металлопроизводящие регионы. При этом воздействие санкций и ответных на них мер Правительства России на экспорт было сильнее, чем на импорт. Ключевые слова: антироссийские санкции; внешняя торговля; импорт; экспорт; ограничения; запреты; экономическая безопасность 